The Philosophical Journal of Conflict and Violence

Vol. II, Issue 2/2018

(C) The Authors 2018

Available online at http://trivent-publishing.eu/

\title{
When Violence Became Beautiful
}

\author{
Boryana Angelova-Igova \\ National Sports Academy Vassil Levski, Bulgaria.
}

\begin{abstract}
In this article, I will look at violence from a different perspective - that is, violence regarded as beautiful. For too long, this perspective has been neglected, considered taboo, and it is precisely due to the controversial character of what the word represents, and to the double standards used when considering it. Namely that, violence can also be a means of expression in art and sports, emphasizing the qualities of the artist or athlete, as well as having an aesthetic and ethical significance. Such violence, of course, needs to be kept within certain limits and subjected to rules. And, as it turns out, sports rules legitimize violence and make it "beautiful".
\end{abstract}

Keywords: Walter Benjamin; Norbert Elias; Paul Ricour; Aesthetics: Ethics; Philosophy of sport; violence.

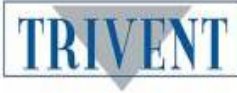

The PJCV Journal is published by Trivent Publishing.

This is an Open Access article distributed in accordance with the Creative Commons Attribution Non Commercial (CC-BY-NC-ND 4.0) license, which permits others to copy or share the article, provided original work is properly cited and that this is not done for commercial purposes. Users may not remix, transform, or build upon the material and may not distribute the modified material (http:/ / creativecommons.org/ licenses/ by-nc/4.0/) 


\title{
When Violence Became Beautiful
}

\author{
Boryana Angelova-Igova \\ National Sports Academy Vassil Levski, Bulgaria
}

\begin{abstract}
In this article, I will look at violence from a different perspective-that is, violence regarded as beautiful. For too long, this perspective has been neglected, considered taboo, and it is precisely due to the controversial character of what the word represents, and to the double standards used when considering it. Namely that, violence can also be a means of expression in art and sports, emphasizing the qualities of the artist or athlete, as well as having an aesthetic and ethical significance. Such violence, of course, needs to be kept within certain limits and subjected to rules. And, as it turns out, sports rules legitimize violence and make it "beautiful".
\end{abstract}

Keywords: Walter Benjamin; Norbert Elias; Paul Ricaur; Aesthetics: Ethics; Philosophy of sport; violence.

\section{Introduction: The notion of "violence"}

The aim of this article is to deconstruct the cliché that hovers around the understanding of the term "violence", namely that violence is a priori evil. To the general public it might look as if everything about violence has been discussed, judged, written, and understood, but this is simply not the case at all. In this paper, I will contend that violence, not just in art, but in sports as well, can be "beautiful", aesthetic, and above all, contain ethical qualities.

Violence has been criticized and discussed by different fields, including philosophy of law, art theory, psychoanalysis, politics, military sciences, etc. As we are going to discuss in further detail in this paper, the very meaning of the term violence is quite flexible. Furthermore, we can safely say that it is a proper "suitcase" term, that is, one that we think is perfectly clear, but that actually contains a variety of meanings packed into it.

Let us consider the philosophical meaning of the term as an example. While the definition varies and covers different meanings and fields, according to Paul Ricœur:

We would be entertaining a very limited and very reassuring idea of violence if we were to reduce it to one of the two extreme forms in which it is entirely and clearly itself: on the one hand murder, that is to say, death inflicted by man on man; or on the other hand, the strength of nature when it attacks man and cannot be tamed by him: the violence of a fire, of a hurricane, of a flood, of an avalanche, the violence of pain, of an epidemies. Between a murder and an avalanche, however, there is the whole realm of the intermediate, which is perhaps violence itself: human violence, the individual as violence. His violence has aspects of the hurricane and of the murder: on the side of the hurricane, it is the violence of desire, of fear, and of hate; on the side of murder, it is the will to dominate the other man, the 
attempt to deprive him of freedom or of expression, it is racism and imperialism. ${ }^{1}$

In fact, violence is not universally legally defined, and the establishment of its prima facie unlawfulness is superficial and often erroneous, because it leaves the possibility of moral justification for its extraordinary use, and in other cases, as in martial arts and boxing, it becomes a pretext for censorship and suppression of former cultural practices.

\section{The Monopoly on Violence}

In "Politics as a Vocation"2 Max Weber insisted that the state has a monopoly on legitimate violence, otherwise there cannot be a state. The police and the army have the right to apply violence when laws and rules in the state or of the sovereign are jeopardized. Violence may be state-sponsored, as well as private (private security guards, etc.). It is, however, legitimized and recognized by the state. If the state abandons its monopoly on violence, we no longer have a state. Despite this mandatory legitimization of the state, there are thousands of examples throughout human history of the state misusing violence; and besides, laws and rules rarely guarantee citizens' rights and make violence justified. Practices of physical or psychological violence have already been instituted—such as war, the death penalty, etc.- - all constituting institutional violence. The same applies to illegal or extralegal practices such as the arbitrary civil enforcement of law, torture, and state terrorism (e.g. the death squads). According to anarchists, courts, prisons, and especially the police turn the state into a system of violence. Legitimate violence from the state towards its people can manifest in the shape of racism and sexism which then can also be viewed as a form of institutional violence because of the associated psychological and physical violence. This demonstrates how the term "violence" is not clearly defined.

Walter Benjamin, in his article "Critique of Violence"3, draws attention to the contradictions that surround the state monopoly over violence. War and/or ill-treatment of protesters and workers on strike can hardly be justified, but, in certain cases war is justified and violent action against strikers is supposedly then justified by the end goal, which is preserving public order. Police force acts violently due to the process of law (it has the right to enforcement), but at the same time it has the authority to lay the same within a wide range of circumstances. As a means, any violence is either law-enforcing or law-protecting. If it does not claim any of these two predicates, then it itself renounces any validity. According to Benjamin, conflicts can be resolved in a non-violent manner, although, a simple call for dialogue (i.e. language, a gesture, etc.) could represent a kind of violence. As Ricœur emphasizes, the confrontation of violence with language underlies all of the problems which we can pose concerning man. "Their encounter occupies such a vast field because violence and language each occupy the totality of the human field." 4 . For example, detention, prison sentences, and other forms of punishment, the death penalty (in some countries), which are all considered basically violent, are not contested, but rather perceived as symbols of statehood and law, and as strange as it may seem, this kind of violence is considered at times even humane. These different perspectives demonstrate the vagueness of the term "violence" and the necessity for diverse perceptions of the notion of violence, one of which could be that it is beautiful.

\footnotetext{
1 Paul Ricœur, Political and Social Essays, (Athens: Ohio University Press, 1974), 32.

2 Max Weber, Essays in Sociology (New York: Oxford University Press, 1946), 77-128.

3 Walter Benjamin, Selected Writings. Volume 1: 1913-1926, ed. Marcus Bullock \& Michael W. Jennings (Cambridge, MA: The Belknap Press of Harvard University Press, 1996), 236-252.

4 Paul Ricœur, Political and Social Essays (Athens: Ohio University Press, 1974), 33.
} 
In relation to sports, violence takes the form either of breaking the rules by those involved in the discipline in question, or in violation of disturbing public order by spectators. Formulated this way, violence should not be confused with fighting spirit or with aggression, which can be good qualities when used without brutality in accordance with the rules 5 . In his article "The Power of Sport in Peacemaking and Peacekeeping," Jim Parry argues "that sport is not about conflict but competition; not about violence but controlled aggression; neither is it amoral and value-free but is itself a moral enterprise.". Moreover, sport is not just a conflict that has to establish superiority. For the cornerstone values of competitive sport include cooperation and equality, which provide the context for competitive activity.

In sport games and art, we can also see a contradiction in terms of violence. Sports and the arts can challenge the state's monopoly over violence in the sense that they have the right to "use" it. Violence is a vital component in some sport games such as boxing, wrestling, martial arts, etc. Much like the controversies typical of the state, as described above, sports games exhibit a similar issue. Undoubtedly, the punch, the kick and the like, etc. are a kind of physical violence, but when they are according to the rules of the sport game, they are its constituent part, a means of expression. Even though such contests can often result in death or the imposition of moderate or severe bodily injury, these actions are judged by the rules of sport, not by the rules enforced in the state. The fight in the ring is completely legitimate as long as it is regulated, and it is precisely what "makes" the game and provokes interest. In this case, the laws of the state are invalid; the rules of the individual game are valid. The state "allows" violence in sport by regulating it in a law on sport. Parry insists that "Boxing is a competition-but not unarmed 'conflict', never mind armed mortal combat"'. In this sense, sport has its own monopoly on violence. Within the boundaries of the sporting game, spectators and contestants get away from everyday life by being taken into the world of sport both emotionally and physically.

This process of legitimizing violence in sport, according to Norbert Elias ${ }^{8}$, began in England, where they went from a power system of forced imposition to parliamentarism, or more precisely, the transition from dueling knights to rhetoric and public debate. At that point, physical power was displaced by intellectual power; however, it needed, and still today needs, to rely on reality. There is this need to sublimate energy that is accumulated by constantly adhering to repressive rules. These were described by Elias with the term "psychologization"”. People become increasingly dependent on different laws, authorities, as they imposed a certain code of conduct, as well as clothing and manners. They needed to get rid of the accumulated negative energy and this is best accomplished through sport. Sport turns into an event. So, wars become "colder," relying on symbols they discover in sports as well. Sport becomes a resemblance of war. However, instead of producing casualties, sport brings real victories. At the same time, sport to this day is the only area in which a person can commit murder, but if it is according to the rules of the game, the perpetrator is not criminally liable for the cause of death. An example of this is boxing, wrestling, martial arts, etc. The popularity of these sports relies entirely on not having many

\footnotetext{
5 Аефтеров, Е, Б. Ангелова, Красиво насилие, сб. Аичност. Мотивация. Спорт. кн. 17, София, HCA Прес. 2012, 72-83. From now on quoted as follows: E. Lefterov \& B. Angelova, "Beautiful violence, Personality," Motivation. Sports 17 (2012): 72-83.

6 Jim Parry, "The Power of Sport in Peacemaking and Peacekeeping," Sport and Society: Cultures, Commerce, Media, Politics 15/6 (2012): 775.

7 Ibid.: 776.

8 Norbert Elias \& Eric Dunning, Quest for Excitement: Sport and Leisure in the Civiliving Process (Oxford: Blackwell, 1986).

${ }^{9}$ Norbert Elias, The Civilizing Process, trans. Edmund Jephcott (Oxford: Blackwell Publishers, 2000).
} 
of the regular public taboos in them. At the same time, spectators of these sports experience much more empathy for those athletes, who fake nothing. Athletes are experiencing real pain, they really get hurt, and they can really die. This explains why athletes are so loved by people. They, unlike actors, do not follow a script, do not play someone else, but are themselves all the time. The broken nose and the eyebrow cut are real (not the result of the work of a makeup artist). Here we are referring to the real, competitive sports, for example in the Olympic Games, not their toxic offspring, described for instance in Roland Barthes' famous essay "The World of Wrestling"

Elias summarizes these changes under the term of "psychologization" of human relations. It is a part of the rationalization of human existence. The defining sign of the "successful" individual is his ability to control his emotions. This is especially true for athletes. Their actions should be as productive and accurate as possible. In this regard, they should also be emotionally stable. Moreover, athletes need to continue the action even when their mind tells them to stop. The normal reaction to violence would be to look away (for the audience) or to stop partaking (for the athlete). However, despite your mind telling you to stop (looking or participating) you keep doing it. What is special about athletes is that they need to build an "economy of pain". An example of it can be found in one to one combat. In his study on boxing in Chicago, Loïc Wacquant focused precisely on the need to control emotions. In parallel to his physical training, a professional boxer must learn to master his feelings in the ring, neither giving in to them nor showing them, for both anger and fear makes the boxer vulnerable and could be detrimental to the outcome of the fight. And this is possible through an "economy of pain", that is, by "raising the threshold of pain tolerance through its controllable routinization". It is necessary to form a "boxing habitus" or learning to hit and to take blows ${ }^{11}$. According to Parry, boxing can be aggressive without being violent. A player can be both forceful and vigorous without seeking to injure or harm anyone. Hurt is not harm, because the boxer may aim to hurt but not to cause lasting harm or injury, he then is not being "violent" in the sense that warfare is ${ }^{12}$.

Athletes themselves choose to cause, but also to bear the pain, in the ring, as they are there by their own will and with a clear perception of the game and its rules. Yet there is a difference in whether they voluntarily participate in a street fight or are fighting in a legal boxing match. In both cases, there may be a signed declaration in which the athlete declares a readiness to play, a certificate that they are prepared and trained to fight, are aware of the consequences and risks of the fight, etc. However, the state has the right to intervene and to declare the fight to be violent because the street is state territory, whereas the rules of the game exist only when inside the ring. In some countries, boxing rules have not changed much since 1865 when John Douglas the $9^{\text {th }}$ Marquess of Queensberry legitimated them in England. Since then, each federation has recognized those rules and applied them in various countries around the world. Since then, matches have been played in the ring, with gloves, a 3 -minute round, counting to 10 in a knock-out, and so on. In most countries, the monopoly on violence resides with the individual sports federation and the state has no right to interfere with the rules imposed by the federation. In this case, the monopoly on violence is disputed by the various federations ${ }^{13}$. In this sense, sport creates its own virtual world where violence is sanctioned only if it is out of the norm of the game, and it is precisely this virtual world that art points itself towards in the $20^{\text {th }}$ century.

10 Roland Barthes, Mythologies (London: Paladin, 1972).

${ }^{11}$ Loïc Wacquant, Body \& Soul: Notebooks of an Apprentice Boxer (Oxford: Oxford University Press, 2014).

12 See Jim Parry, "The Power of Sport in Peace-making and Peacekeeping".

${ }^{13}$ See E. Lefterov \& B. Angelova, "Beautiful violence, Personality": 72-83 


\section{Art vs. Sport}

As with sports, art often depicts violence, trying to identify its impact on the audience. In art, unlike in sports, there are different rules. The artist is free to portray, tolerate violence, physically or mentally, without confining it to a set of predetermined rules. That would have been more than logical if it was happening only in the imaginary world of the artist, in their work, but there is also evidence of crossing the boundary between reality and fiction. Examples of the passage of this border are Viennese Actionism, happenings, performances, Futurism, etc. In overexposing violence, the artist rejects rules, norms, and normality, and seeks freedom, truth, and beauty. Once again, we see the state monopoly on violence being challenged, this time by art.

Certainly, artists are often persecuted, convicted, repressed, censored ... The cases of the Vienna actionists are indicative. Their art happens on the street, "live," the female body is stripped, dipped in red paint, and printed on paper. Artists self-flagellate in the streets, fight ... continue the tradition of Antonin Artaud's Theatre of Cruelty ${ }^{14}$. Here, however, the state does not easily part with its monopoly, or at least not so quickly. The state, according to José Ortega y Gasset, came out of the sports game back in ancient times, with the latter fighting for the monopoly on violence since about that time ${ }^{15}$.

The situation is a bit different with art. For example, Viennese actionists had been arrested, tried, and jailed, while the rest of them were forced to flee Austria and seek refuge in other countries. Ultra-radical Viennese actionists were Hermann Nitsch, Günter Brus, Otto Muehl, Rudolf Schwarzkogler, Kurt Kren and Alphonse Schilling. Hermann Nitsch was regarded as one of the main initiators of the movement. His ritual-orgiastic performances with naked bodies and animal blood brought him no less than three effective sentences. Otto Muehl's activity was even more extreme. In his "celebrations of psychophysical naturalism," he tormented the human body and turned it into a repulsive antipode of the very notion of conditional beauty. His experiments in a sex commune had sent him behind bars for 7 years. Günter Brus used radically his own body as a tool of actionism—as a basis for "auto-painting" or as an object of his masochistic "stress test". Together with other Viennese actionists, during the rebellious year of 1968, he took part in the Art and Revolution action at the University of Vienna, and as a result of that was sentenced to six months in prison for "defiling state symbols"16. Modern art imposes a new understanding of beauty, that is, violence can be "beautiful". Sports does this as well. According to Aristotle, sports create an alternative reality, more specifically he refers to the first Ancient Olympic games from which drama sprung as a form of art. Furthermore, Aristotle believes that sports spectators experience a more profound catharsis than the audience of a drama because they never know what will happen to the athletes and thus have a higher level of empathy because everything is real (i.e., contrary to actors, the athletes' efforts, tension, and pain are not simulated). Additionally, Johan Huizinga ${ }^{17}$ believes that arts and sports were the same thing up to the $20^{\text {th }}$ century when sports became commercialized and became detached from arts. Therefore, we can deduct that sport and art have the same goal-to be beautiful in order to provide spectators with aesthetic pleasure.

Sports fit into this new aesthetic in their own way-violence is beautiful-it is a rebellion, a protest. However, there are quite a few examples of a sporting matches being

\footnotetext{
${ }_{14}$ See Antonin Artaud, The Theater and Its Double, trans. Mary C. Richards (New York: Grove Press, 1994).

${ }^{15}$ See "The Sportive Origin of the State" in José Ortega y Gasset, History as a System and Other Essays Toward a Pbilosophy of History (New York: W.W. Norton \& Company, 1962), 13-42.

${ }^{16}$ E. Lefterov \& B. Angelova, "Beautiful violence, Personality".

17 Johan Huizinga, Homo Ludens (Boston: Beacon Press, 1971).
} 
banned or having its rules interfered with by the state. In amateur boxing, for instance, in order to please someone's strange politics, the regulations were changed for a while ${ }^{18}$. A rule got imposed that only the accurate strong punch was to be awarded points and judges gradually began to ignore blows with the front-placed arm (which make a boxer's game and give an advantage to the more powerful players). It was enough to land 2-3 accurate punches, then stand in defense and win with a 3 to 1 score. Movement of the body and legs, work with the front arm did not count, which led to changes in the style of play and respectively to the outflow of audience. Amateur boxing matches had to be held in empty halls, with a minimum of spectators, and at the same time the halls where professional boxing was held burst at the seams and the matches were broadcast on television and watched by millions. As a result, the old rules were restored, and amateur boxers gained fans once more. The technical and attractive styles of play regained their interest ${ }^{19}$.

This example shows how state interference with a game leads to its marginalization. The technique and beauty of the game, even the violence inherent in it, are of great importance. Any suppression of violence within a game limits the players' freedom of expression. Violence, in this sense, becomes beautiful, it is a provocation, a rebellion against the status quo, and as such has an aesthetic value and makes empathy acceptable.

\section{Beautiful Violence}

Following the horrors of the $20^{\text {th }}$ century, the two world wars, the concentration camps, totalitarianism, etc., we need to reconsider our understanding of what is "beautiful". Theodor Adorno, for example, wonders whether the production of a work of art is possible after Auschwitz. The answer is precisely in the overexposure to violence in "art breaking away from common sense," 20 in the display of the barbarous nature of man. Contemporary art, according to Marcuse, must be the art of "the big no", denying everything to this point and distancing itself from everything to this point. Art should not be merely an ornament to a depressing reality in the totalitarian era. Rather, it should be in opposition, highlighting the mismatch between the artistic form and the surrounding world. Marcuse's argument is influenced by Bertolt Brecht's theory of the Verfremdungseffekt (i.e., "estrangement effect" or "defamiliarization effect"), according to which the world must be shown as a negative state that must be denied and changed. Artaud's theater is indicative in this sense. He allows a real fight on stage, mimicking many of the sports games like boxing and martial arts. Actors really hurt each other, copulate, live the scenes of violence on stage. The regulations imposed by the theater script have been removed. Theater is looking for the connection with life in the city, on the street, at home: the real thing. The same thing happens in sports as well, everything there is for real ${ }^{21}$.

This search for a daring new aesthetic understanding of beauty during the mid- $20^{\text {th }}$ century is often experienced by audiences as a shock which is caused by the contrast that breaks the chain of everyday experience and uncovers a different reality. This reality is radically different from the reality of the zombie citizen. All the means that express this reality are alien to the everyday language of the agent of "technological reasoning" 22 . Its

\footnotetext{
18 Аефтеров, Е.,Ангелова - Игова, Б., Утвърждаващият и интегриращият бокс, в сп. „Спорт и наука“, 2014 [E. Lefterov \& B. Angelova-Igova, "Confirming and Integrating Boxing," in Sport and Science (2014).]

19 See E. Lefterov \& B. Angelova, "Beautiful violence, Personality".

20 Teodor Adorno, Aesthetic Theory (London: Routledge \& Kegan Paul, 1984).

21 Аефтеров, Е, Б. Ангелова .Красиво насилие, сб. Аичност. Мотивация. Спорт. кн. 17, София, HCA Прес. 2012, $72-83$ [Lefterov, E, B. Angelova. "Beautiful violence, Personality," Motivation. Sports. 17 (2012): 72-83]

22 Herbert Marcuse, One-Dimensional Man (New York: Routledge\& Kegan Paul, 2002).
} 
image is surreal. This requires a "new sensitivity," a new language. Scenes of violence are particularly characteristic, since we rarely see them in our organized bourgeois life. When we are faced with scenes of violence, we comprehend the transience and falsity of our daily lives. The same is true of the films of Pasolini, that overexpose violence and sexuality to remind of the horrors of fascism; the contemporary Bulgarian art group "Ultrafuturo" (Boryana Rosa and Oleg Mavromati) literally sew their bodies together on stage, branding their skin, flaying it. Such performances cause aversion, shock, horror, but the truth is that these are the facts of life. This is how many human beings suffer in the Third World, in the neighboring Roma ghetto, but people prefer not to realize it. The flayed animals we wear, the poisonous food we eat or steal from Africa and throw away in the garbage ... all are facts of life we prefer not to think about, but contemporary artists-these "cuckoos" do not allow us that, they dare to provoke us, interrupt our sleep and our peace of mind.

This has always been done by sports games, boxing, wrestling, karate, etc. They are spectacles that could be perceived on several levels. To some it is barbarism, usually garnished with blood and knocked out teeth; to others, it is magic, performance, a clash of titans, characters, fighting techniques, body set-up. The strike itself is beautiful, the good performance brings "points". A beautiful accurate strike must be practiced-it is the fruit of years of training to improve the technique and tactics of the athlete. In boxing we talk about the beauty of the blow. Taken out of its context, a blow is a blow, that is, a kind of violence, but, in the sportive context, the blow can be beautiful. The athlete strives to "hit beautifully," paired with the defense that keeps them from the opponent's attacks. In the match, punches landed are taken into consideration, whether the attack and the defense are in full sync with the movement of the legs and the body. The more perfected movements are, the more effective and more aesthetically-attractive the competitor is. A game opposing equally good or weak boxers rarely ends with a knockout or technical knock-out. Furthermore, an equal number of points may have been assigned to both boxers on the ring. In this case, the referee evaluating the match gives the advantage to the more technical, more aesthetically-attractive athlete, the one using more sophisticated and beautiful techniques ${ }^{23}$. In boxing, and in most sports games, there is a referee who legitimizes the violence and judges whether it is "beautiful" enough. Beauty is assessed through rules. There are several columns on the judging slip which are filled in order to decide the winner. The referee is just like the art critic-he gives estimates, but they are always subject to doubt. In boxing, superior technique is evaluated first and foremost, second comes the better style, third is the activity, and fourth-everything else. To pick a winner in a situation with equal number of points, one of these columns is filled, a score is given and indicated by the audience as well through its level of applause (rewarding the more aestheticallyattractive athlete). Rough, brutal contestants, who have a strong punch and poor technique are condescendingly named "sluggers". They can also be applauded when they beat someone in the ring, but when a slugger and a technical fighter (e.g., an out-boxer) meet, audiences and judges generally support the more technical athlete who embodies the beauty of the game. However, sluggers are also of interest to the masses. Undoubtedly the knockout is quite attractive, but the connoisseurs of the game prefer the technical game because it brings aesthetic delight to the spectator and is a testimony to better knowledge of the game, to more training and absorption in the art of boxing. An honest player who does not allow himself punches under the belt and respects his opponent is among the most loved; usually boxing aficionados are also fans of fair play and real sportsmen. Parry argues that violence in sport presents opportunities for moral education and moral development. Because when people play sport, they exercise their potential for aggression and can thereby

${ }^{23}$ See E. Lefterov \& B. Angelova, "Beautiful violence, Personality". 
test, experience and train their virtue of humanity. During the game they may be tempted by the attraction of violence in pursuit of their aims. According to Parry sports and games can function as laboratories for value experiment, in which players are "put in the position of having to act, time and time again, sometimes in haste, under pressure or provocation, either to prevent or to achieve something, under a structure of rules" 24 . They can act honestly or play "dirty" but, in contrast with the "real" life, participants in combat sport have time to rethink the situation, to regret or to be proud of their actions. So, from an ethical perspective, sports can obviously be very useful both for spectators and players. The opportunities regarding the promotion of positive ethical values are tremendous. Sport can be an excellent vehicle for the apprenticeship and conservation of moral and political values. Freedom, responsibility, equality, justice and respect-all these are to be found in the rule-based practices of sport ${ }^{25}$.

According to Ernst Cassirer ${ }^{26}$, during the 20th century the beauty of art-and we could add sports as well-became a matter of connoisseurs. Consequently, a higher level of commitment and expertise regarding the knowledge of the arts of sport is required today. This new context divides modern sport audiences into two groups: the masses who merely enjoy the fashion, blood, suspense, and emotion of the sport show; the "specialists" who, with their more refined aesthetic knowledge, enjoy watching every detail of the sportsmen's' gestures, and who are familiar with the concept, the purpose, the "stories" behind sportsmen's performances.

Hence, I hope I have demonstrated in my aesthetic study on sports that violence can be regarded as "beautiful". With respect to sports, violence is a means of expression. Violence is subject to evaluation and interpretation. Violence has a social function and purpose. The extent to which this violence is understood, however, depends on the nature of the audience and its knowledge of the given arts of sport.

\section{References}

Adorno, Theodor. Aesthetic Theory. London: Routledge \& Kegan Paul, 1984.

Artaud, Antonin. The Theater and Its Double. Translated by Mary C. Richards. New York: Grove Press, 1994.

Barthes, Roland. Mythologies. London: Paladin, 1972.

Baudrillard, Jean. The Consumer Society: Myths and Structures. New York: SAGE books, 1970.

Benjamin, Walter. Selected Writings. Volume 1:1913-1926. Edited by Marcus Bullock \& Michael W. Jennings. Cambridge, MA: The Belknap Press of Harvard University Press, 1996.

Elias, Norbert. The Civilizing Process. Translated by Edmund Jephcott. Oxford: Blackwell Publishers, 2000.

Elias, Norbert \& Eric Dunning. Quest for Excitement: Sport and Leisure in the Civilizing Process. Oxford: Blackwell, 1986.

Cassirer, Ernst. The Philosophy of Symbolic Forms. New Haven: Yale University Press, 1953.

Huizinga, Johan. Homo Ludens. Boston: Beacon Press, 1971.

Marcuse, Herbert. One-Dimensional Man, New York: Routledge \& Kegan Paul, 2002.

Ortega y Gasset, José. History as a System and Other Essays Toward a Philosophy of History. New York: W.W. Norton \& Company, 1962.

${ }^{24}$ Jim Parry, "The Power of Sport in Peacemaking and Peacekeeping," Sport and Society: Cultures, Commerce, Media, Politic (2012): 777-778.

${ }^{25}$ See ibid., 775-787.

26 Ernst Cassirer, The Philosophy of Symbolic Forms (New Haven: Yale University Press, 1953). 
Ricour, Paul. Political and Social Essays. Athens: Ohio University Press., 1974.

Parry, Jim. "The Power of Sport in Peacemaking and Peacekeeping." Sport and Society: Cultures, Commerce, Media, Politics 15/6 (2012): 775-787.

Wacquant, Loïc. Body \& Soul: Notebooks of an Apprentice Boxer. New York: Oxford University Press, 2014.

Weber, Max. Essays in Sociology. New York: Oxford University Press, 1946.

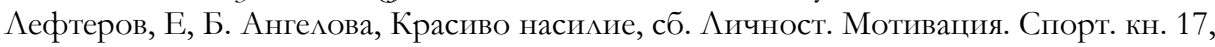
София, НСА Прес, 2012, 72-83, [E. Lefterov, B. Angelova. "Beautiful violence." Personality. Motivation. Sports. 17 (2012): 72-83.]

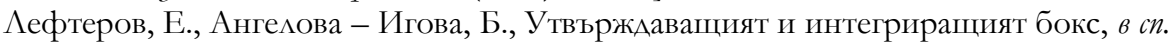
„Спорт и наука“, София, НСА-Прес, 2014, [E. Lefterov, B. Angelova-Igova.

"Confirming and Integrating Boxing." In Sport and Science. Sofia: NSA-Press, 2014]. 